\title{
Prevalence of congenital malformations and genetic diseases in Korea
}

\begin{abstract}
A nationwide investigation of congenital malformations and genetic diseases in Korea was conducted by analyzing Medical Insurance data for infants aged under 1 year. Medical Insurance data were obtained for 1993 and 1994 and the ICD-9 (International Classification of Diseases, Ninth Revision) code was used to classify the diseases. The coverage rate of medical insurance was approximately $95 \%$ of the total population. Anomalies of the cardiovascular, musculoskeletal, and gastrointestinal systems, in descending order of frequency, were more frequent than anomalies in other systems. The average prevalence of cardiovascular anomalies for 1993 and 1994 was 15 per 1000 infants, and ventricular septal defect, with an average prevalence of about 3.50 per 1000 for 1993 and 1994, was the most frequent cardiovascular anomaly in infants. Polydactyly was the most frequent musculoskeletal anomaly, with an average prevalence, for 1993 and 1994, of about 1.20 per 1000 infants. Anencephaly had the highest frequency of nervous system anomalies. Congenital hypertrophic pyloric stenosis was the most common of the gastrointestinal anomalies. The prevalence of the congenital malformations and genetic diseases examined was similar to that reported in other countries. Total medical expenses for the care of patients with each disease entity were also estimated. The highest medical expenses were incurred for ventricular septal defect, congenital coagulation factor VIII disorders, atrial septal defect, tetralogy of Fallot, and spinal anomalies, in descending order of magnitude. This investigation could be helpful in planning social welfare systems, as well as for elucidating the current status of congenital malformations and genetic diseases in Korea, and in other Asian countries.
\end{abstract}

S.-C. Jung $(\bowtie) \cdot$ S.-S. Kim $\cdot$ K.-S. Yoon $\cdot$ J.-S. Lee

Division of Genetic Disease, National Institute of Health, Nokbun-

Dong 5, Eunpyung-Gu, Seoul 122-701, Korea

Tel. +82-2-380-1534; Fax +82-2-388-0924

e-mail: jungsc@nih.go.kr

J.-S. Lee

Department of Pediatrics, Yonsei University College of Medicine,

Seoul, Korea
Key words Congenital malformations - Genetic diseases · Prevalence $\cdot$ Infant $\cdot$ Korea

\section{Introduction}

In all countries, the priorities for medical approaches to genetic diseases depend upon the local frequencies of those diseases, the health care burden that they represent, the possibilities for prevention and treatment, available resources, and the health care infrastructure. Congenital malformations and genetic diseases can be of varying degrees of severity, may have, at onset, any degree of severity, and the onset may be at any stage in the patients lifetime. However, those diseases in which symptoms are presented at birth are particularly burdensome, because they may cause early death or lifelong disability. Investigation on the prevalence of genetic diseases is important not only as a matter of medical interest but also for the planning of social welfare systems. In developed countries, congenital and genetic disorders are the second most common cause of death in infancy and childhood (Forfar 1992), and in those countries the incidence of births of infants with congenital disorders, including disorders that are regarded as trivial or relatively easily corrected (such as Congenital hypertrophic pyloric stemosis and polydoctyly), is about 2560 per 1000 (WHO Scientific Group 1996). Approximately $20 \%$ of all conceptions result in fetuses that have a chromosomal disorder, but most of these fail to implant or are spontaneously aborted, so that the birth frequency of infants with chromosomal disorders is $0.6 \%$ (Connor and Ferguson-Smith 1997).

There have been reports of congenital malformations and genetic diseases in Korea, but, as most of them were based on data from single hospitals or limited areas, they could not represent the status of genetic diseases in the country as a whole. Therefore, we investigated nationwide medical insurance data and analyzed these data to elucidate the current status of congenital malformations and genetic diseases in Korea. 


\section{Subjects and methods}

Medical insurance benefit data from the Korean Federation of Medical Insurance were examined for 1993 and 1994. The coverage rate of medical insurance was approximately $95 \%$ of the total population. The medical insurance benefit data originally included all medical activities for diagnosis and treatment. Information on the insurance society, type of medical care institution, episodes of hospital admission, national identification number, birthday, day of first visit, days of visits, major disease code, and total expenses was collected. We used the International Classification of Diseases, Ninth Revision (ICD-9) to classify genetic diseases and congenital malformations. For congenital anomalies, ICD-9 codes 740.0-759.9 were investigated, except for the chromosomal anomalies (ICD-9, 758.0-758.9). All candidate codes for single gene disorders and other congenital anomalies that were not included in ICD-9 codes 740.0 759.9 were also investigated. The disease data were analyzed according to the four-digit subcategory of ICD-9. To avoid double registration of a patient, spell-based data were converted to person-based by national identification number and disease code. Therefore patients with multiple anomalies could be counted separately with different disease codes. Data from pharmacies, dental clinics, and oriental medical clinics were excluded because of the unreliability of diagnosis. Prevalences were calculated using the number of infants below age 1 year among medical insurance dependants as the denominator. To estimate medical expenses for the care of patients with congenital malformations and genetic diseases, insurance benefits and patient-charged consultation fees were also investigated.

\section{Results}

Medical insurance covered approximately $95 \%$ of the total Korean population in 1993 and 1994. Of the population of infants aged under 1 year, 601,376 were covered by medical insurance in 1993 and 601,459 in 1994. The overall prevalence of congenital malformations per 1000 infants aged less than 1 year was 39.3 in 1993 and 34.4 in 1994. Cardiovascular anomalies were the most common congenital malformations in infants. The second most common were musculoskeletal anomalies, with the third most common, gastrointestinal anomalies. The prevalence of cardiovascular anomalies was 15.6 per 1000 infants in 1993 and 14.0 in 1994 (Table 1).

Anencephaly was the most frequent congenital anomaly of the nervous system (Table 2), with a prevalence of 0.26 per 1000 infants in 1993 and 0.42 in 1994. The prevalence of spina bifida was also high ( 0.30 per 1000 infants in 1993 and 0.27 in 1994) among nervous system anomalies. The most frequent cardiovascular anomaly was ventricular septal defect, and its prevalence per 1000 infants was 3.59 in 1993 and 3.24 in 1994. Pulmonary valve anomalies were the second most common cardiovascular anomaly, followed by,
Table 1 Prevalence of congenital anomalies by system in infants aged less than 1 year in Korea

\begin{tabular}{|c|c|c|c|c|}
\hline \multirow[b]{2}{*}{ System (ICD-9) } & \multicolumn{2}{|c|}{$\begin{array}{l}\text { Number of } \\
\text { patients }\end{array}$} & \multicolumn{2}{|c|}{$\begin{array}{l}\text { Prevalence } \\
(/ 1000)\end{array}$} \\
\hline & 1993 & 1994 & 1993 & 1994 \\
\hline $\begin{array}{c}\text { Nervous system } \\
(740.0-742.9)\end{array}$ & 632 & 669 & 1.05 & 111.2 \\
\hline $\begin{array}{l}\text { Eye, ear, face, and neck } \\
\quad(743.0-744.9)\end{array}$ & 2,988 & 2,613 & 4.96 & 434.4 \\
\hline $\begin{array}{l}\text { Circulatory system } \\
(745.0-747.8)\end{array}$ & 9,367 & 8,398 & 15.58 & 13.96 \\
\hline $\begin{array}{l}\text { Respiratory system } \\
\quad(748.0-748.9)\end{array}$ & 187 & 166 & 0.31 & 0.27 \\
\hline $\begin{array}{l}\text { Digestive system } \\
\quad(750.0-751.9)\end{array}$ & 4,432 & 3,839 & 7.37 & 6.38 \\
\hline $\begin{array}{l}\text { Urogenital system } \\
\quad(752.0-753.9)\end{array}$ & 602 & 581 & 1.00 & 0.96 \\
\hline $\begin{array}{l}\text { Musculoskeletal system } \\
\quad(754.0-756.9)\end{array}$ & 5,260 & 4,251 & 8.75 & 7.07 \\
\hline $\begin{array}{l}\text { Skin and appendages } \\
\quad(757.0-757.9,759.0-759.9)\end{array}$ & 167 & 153 & 0.28 & 0.25 \\
\hline Total & 23,635 & 20,670 & 39.30 & 34.37 \\
\hline
\end{tabular}

ICD, International classification of diseases, 9th revision

Table 2 Prevalence of congenital anomalies of nervous system in infants aged less than 1 year in Korea

\begin{tabular}{lrrrlll}
\hline & \multicolumn{2}{l}{$\begin{array}{l}\text { Number of } \\
\text { patients }\end{array}$} & & \multicolumn{2}{l}{$\begin{array}{l}\text { Prevalence } \\
(/ 1000)\end{array}$} \\
\cline { 2 - 3 } \cline { 6 - 7 } Disease & 1993 & 1994 & & 1993 & 1994 \\
\hline Anencephaly & 156 & 255 & & 0.26 & 0.42 \\
Spina bifida & 178 & 162 & & 0.30 & 0.27 \\
Encephalocele & 65 & 48 & & 0.11 & 0.08 \\
Microcephalus & 28 & 33 & & 0.05 & 0.06 \\
Congenital hydrocephalus & 103 & 87 & & 0.17 & 0.15 \\
\hline
\end{tabular}

Table 3 Prevalence of cardiovascular anomalies in infants aged less than 1 year in Korea

\begin{tabular}{lrrrlll}
\hline & \multicolumn{2}{c}{$\begin{array}{l}\text { Number of } \\
\text { patients }\end{array}$} & & \multicolumn{2}{l}{$\begin{array}{l}\text { Prevalence } \\
\text { (/1000) }\end{array}$} \\
\cline { 2 - 3 } Disease & 1993 & 1994 & & 1993 & 1994 \\
\hline Transposition of great vessels & 180 & 166 & & 0.30 & 0.28 \\
Tetralogy of Fallot & 421 & 458 & & 0.70 & 0.76 \\
Ventricular septal defect & 2158 & 1946 & & 3.59 & 3.24 \\
Ostium secundum type atrial & 591 & 574 & & 0.98 & 0.95 \\
$\quad$ septal defect & & & & \\
Endocardial cushion defects & 91 & 82 & & 0.15 & 0.14 \\
Pulmonary valve anomalies & 1471 & 1305 & & 2.45 & 2.17 \\
Ebstein's anomaly & 37 & 20 & & 0.06 & 0.03 \\
Patent ductus arteriosus & 479 & 367 & & 0.80 & 0.61 \\
\hline
\end{tabular}

in descending order, atrial septal defect, patent ductus arteriosus, and tetralogy of Fallot (Table 3). Congenital hypertrophic pyloric stenosis was the most frequent gastrointestinal anomaly. Its prevalence was 1.81 per 1000 infants in 1993 and 1.53 in 1994. The prevalence of cleft lip with or without cleft palate was about 1.0 per 1000 infants in both 1993 and 1994. The prevalence of congenital 
Table 4 Prevalence of gastrointestinal anomalies in infants aged less than 1 year in Korea

\begin{tabular}{|c|c|c|c|c|}
\hline \multirow[b]{2}{*}{ Disease } & \multicolumn{2}{|c|}{$\begin{array}{l}\text { Number of } \\
\text { patients }\end{array}$} & \multicolumn{2}{|c|}{$\begin{array}{l}\text { Prevalence } \\
(/ 1000)\end{array}$} \\
\hline & 1993 & 1994 & 1993 & 1994 \\
\hline Cleft palate & 448 & 368 & 0.75 & 0.61 \\
\hline Cleft lip & 648 & 579 & 1.08 & 0.96 \\
\hline Cleft palate with cleft lip & 254 & 285 & 0.42 & 0.47 \\
\hline Tongue tie (ankyloglossia) & 359 & 271 & 0.60 & 0.45 \\
\hline $\begin{array}{l}\text { Tracheo-esophageal fistula, esophageal } \\
\text { atresia and stenosis }\end{array}$ & 101 & 88 & 0.17 & 0.15 \\
\hline Congenital hypertrophic pyloric stenosis & 1087 & 917 & 1.81 & 1.53 \\
\hline $\begin{array}{l}\text { Atresia and stenosis of large intestine, } \\
\text { rectum, and anal canal }\end{array}$ & 337 & 295 & 0.56 & 0.49 \\
\hline $\begin{array}{l}\text { Congenital megacolon (Hirschprung's } \\
\text { disease and other congenital } \\
\text { functional disorders of colon) }\end{array}$ & 479 & 411 & 0.80 & 0.68 \\
\hline $\begin{array}{l}\text { Gallbladder, bile duct, and liver } \\
\text { anomalies }\end{array}$ & 189 & 161 & 0.31 & 0.27 \\
\hline
\end{tabular}

Table 5 Prevalence of urogenital anomalies in infants aged less than 1 year in Korea

\begin{tabular}{lrrrlll}
\hline & \multicolumn{2}{l}{$\begin{array}{l}\text { Number of } \\
\text { patients }\end{array}$} & & \multicolumn{2}{l}{$\begin{array}{l}\text { Prevalence } \\
\text { (/1000) }\end{array}$} \\
\cline { 2 - 3 } Disease & 1993 & 1994 & & 1993 & 1994 \\
\hline Ovarian anomalies & 20 & 19 & & 0.03 & 0.03 \\
Undescended testis & 162 & 151 & & 0.27 & 0.25 \\
Hypospadias and epispadias & 45 & 33 & & 0.08 & 0.06 \\
Renal agenesis and dysgenesis & 44 & 31 & & 0.07 & 0.05 \\
Cystic kidney disease & 43 & 38 & & 0.07 & 0.06 \\
\hline
\end{tabular}

megacolon was about 0.80 per 1000 infants in 1993 and 0.68 in 1994 (Table 4). The frequency of urogenital anomalies was extremely low, with undescended testis being the most frequent, with a prevalence of about 0.25 per 1000 male infants in 1993 and 1994 (Table 5). Polydactyly was the most frequent of the musculoskeletal anomalies with a prevalence of about 1.41 per 1000 infants in 1993 and 1.22 in 1994. The prevalence of congenital dislocation of the hip was about 1.10 per 1000 infants in 1993 and 0.93 in 1994, with the prevalence of varus deformity of feet about 0.83 in 1993 and 0.55 in 1994 (Table 6). Of the single gene disorders investigated (Table 7), the prevalence of adrenogenital disorders was 0.28 per 1000 infants in 1993 and 0.30 in 1994. Phenylketonuria was rare, with a prevalence of 0.01 per 1000 infants in 1993 and 0.02 in 1994. Mucopolysaccharidosis was also rare (0.01 per 1000 infants in 1993 and 1994). The prevalence of congenital coagulation factor VIII disorders was 0.22 per 1000 infants in 1993 and 0.15 in 1994 (0.16 per 1000 male infants in 1993, 0.11 in 1994).

Total medical expenses for the care of patients with each congenital malformation and genetic disease entity were relatively high. The greatest expenses incurred were for ventricular septal defect, congenital coagulation factor VIII disorders, atrial septal defect, tetralogy of Fallot, and spinal anomalies, in descending order of magnitude. Total medical expenses for patients with ventricular septal defect were
Table 6 Prevalence of musculoskeletal anomalies in infants aged less than 1 year in Korea

\begin{tabular}{lrrrll}
\hline & \multicolumn{2}{l}{$\begin{array}{l}\text { Number of } \\
\text { patients }\end{array}$} & & \multicolumn{2}{l}{$\begin{array}{l}\text { Prevalence } \\
\text { (/1000) }\end{array}$} \\
\cline { 2 - 3 } Disease & 1993 & 1994 & & 1993 & 1994 \\
\hline Congenital dislocation of hip & 663 & 560 & & 1.10 & 0.93 \\
Varus deformity of feet & 499 & 331 & & 0.83 & 0.55 \\
Valgus deformity of feet & 99 & 55 & & 0.17 & 0.09 \\
Polydactyly & 845 & 734 & & 1.41 & 1.22 \\
Syndactyly & 155 & 173 & & 0.26 & 0.29 \\
Spinal anomalies & 87 & 95 & & 0.15 & 0.16 \\
Cervical rib & 9 & 6 & & 0.02 & 0.01 \\
Chondrodystrophy & 35 & 14 & & 0.06 & 0.02 \\
Diaphragmatic anomalies & 72 & 47 & & 0.12 & 0.08 \\
Abdominal wall anomalies & 79 & 42 & & 0.13 & 0.07 \\
\hline
\end{tabular}

Table 7 Prevalence of some single gene disorders in infants aged less then 1 year in Korea

\begin{tabular}{|c|c|c|c|c|}
\hline \multirow[b]{2}{*}{ Disease } & \multicolumn{2}{|c|}{$\begin{array}{l}\text { Number of } \\
\text { patients }\end{array}$} & \multicolumn{2}{|c|}{$\begin{array}{l}\text { Prevalence } \\
(/ 1000)\end{array}$} \\
\hline & 1993 & 1994 & 1993 & 1994 \\
\hline Adrenogenital disorders & 168 & 182 & 0.28 & 0.30 \\
\hline Phenylketonuria & 2 & 5 & 0.01 & 0.02 \\
\hline Mucopolysaccharidosis & 2 & 2 & 0.01 & 0.01 \\
\hline Hereditary spherocytosis & 37 & 26 & 0.12 & 0.09 \\
\hline Thalassemias & 2 & 1 & 0.01 & 0.01 \\
\hline $\begin{array}{l}\text { Congenital coagulation } \\
\text { factor VIII disorders }\end{array}$ & 68 & 48 & 0.22 & 0.15 \\
\hline $\begin{array}{l}\text { Congenital coagulation } \\
\text { factor IX disorders }\end{array}$ & 2 & 5 & 0.01 & 0.02 \\
\hline
\end{tabular}

about 7 billion Korean won (US \$7,778,000), and for patients with congenital coagulation factor VIII disorders, about 5 billion Korean won (US $\$ 5,556,000$ ), in 1993. The order was similar in 1994, but the expenses were slightly lower (Table 8).

\section{Discussion}

In evaluating the epidemiological study of congenital malformations, different methods of case ascertainment can give rise to considerable variability in estimating prevalence; this is a significant problem worldwide. The reported prevalence of congenital malformations ranges from 30 to 50 per 1000 births, depending on study methods and diagnostic criteria. Our study was not based on medical record review but on medical insurance benefit data. These data had several limitations. The case ascertainment was relatively incomplete, because some disease codes for these data were based on tentative diagnoses. The disease data were analyzed by four-digit subcategory of ICD-9, but a proportion of disease records had been reported with the wrong code, which was not included in the ICD-9 system; we assumed this was because of input or recording error. In these cases we regarded the record as being included in the corresponding three-digit category; therefore, the fre- 
Table 8 Total expenses for the care of infants, aged less than 1 year, with genetic diseases and congenital malformations in Korea

\begin{tabular}{|c|c|c|c|c|}
\hline \multirow{2}{*}{$\begin{array}{l}\text { Year } \\
\text { Rank }\end{array}$} & \multicolumn{2}{|l|}{1993} & \multicolumn{2}{|l|}{1994} \\
\hline & Disease & Total expenses ${ }^{\mathrm{a}}$ & Disease & Total expenses \\
\hline 1 & Ventricular septal defect & 7062 & Ventricular septal defect & 5544 \\
\hline 2 & Congenital coagulation factor VIII disorders & 4974 & Congenital coagulation factor VIII disorders & 4812 \\
\hline 3 & Ostium secundum type atrial septal defect & 3423 & Ostium secundum type atrial septal defect & 2625 \\
\hline 4 & Tetralogy of Fallot & 2221 & Tetralogy of Fallot & 1854 \\
\hline 5 & Spinal anomalies & 1810 & Spinal anomalies & 1465 \\
\hline 6 & Other specified anomalies of circulatory system & 1102 & Undescended testis & 895 \\
\hline 7 & Undescended testis & 1072 & Other specified anomalies of circulatory system & 871 \\
\hline 8 & Patent ductus arteriosus & 1005 & Patent ductus arteriosus & 793 \\
\hline 9 & Transposition of great vessels & 833 & Transposition of great vessels & 766 \\
\hline 10 & Cleft palate & 753 & Cleft palate & 741 \\
\hline
\end{tabular}

${ }^{a}$ Total expenses, shown in million Korean won (exchange rate of US\$ to Korean won was about 1:900 in 1993 and 1994)

quency and prevalence of diseases in our report by the fourdigit subcategory were somewhat underestimated.

The overall prevalence of congenital anomalies in our study was similar to that reported in other studies in Korea (Chi 1987, Park et al. 1993). The prevalence of anencephaly was lower than that reported in Los Angeles County, USA (Sever 1982) and Osaka city, Japan (Imaizumi et al. 1991). The estimated prevalence of neural tube defects, including anencephaly, spina bifida, and encephalocele, was $0.67-0.77$ per 1000 infants, which was very much lower than that in other countries (Congenital Malformations Worldwide, International Clearinghouse 1991). The prevalence of ventricular septal defect was higher than that in the United States (Ferencz 1990, Gillum 1994, Grabitz et al. 1988), but the frequencies of other cardiovascular anomalies were similar to those in other countries (Connor and FergusonSmith 1997, Hanna et al. 1994). Congenital hydrocephalus was less common than in Utah, United States (Blackburn and Fineman 1994); however, our prevalence data may have been underestimated, as many cases of congenital hydrocephalus were counted as neural tube defects in our medical insurance data. The prevalence of cleft lip and cleft palate was similar to that in western countries (Farhud et al. 1986, Connor and Ferguson-Smith 1997). Among Asian countries, Japan (Natsume et al. 1987) also showed a similar prevalence (2.06 per 1000 births), but China (Xiao 1989) and Singapore (Thein et al. 1992) showed slightly lower figures (1.82 and 1.72 per 1000 births apiece). The prevalence of congenital hypertrophic pyloric stenosis was similar to that in New York, United States, and other countries (Applegate and Druschel 1995). Hirschprung's disease and diaphragmatic anomalies, including congenital diaphragmatic hernia, were less common than in the United States (Goldberg 1984, Cannon et al. 1996).

We also invetigated the prevalences of single gene disorders. The prevalence of adrenogenital disorders was higher than that reported in Sweden (Thilen and Larsson 1990). The rate of congenital factor VIII disorders was similar to that in other countries (Mosher 1996).

We studied medical expenses for the care of patients with each disease category in order to investigate the health care load of congenital malformations and genetic diseases borne by Korean society. In 1993, the total medical expense for congenital anomalies (ICD-9, 740.0-759.9) was 36 billion Korean won (US\$ 40 million). Although this figure ranked fourteenth among 18 disease categories in descending order of magnitude of expense, it ranked second in order of expenses per claim in 1993 (Korean National Federation of Medical Insurance 1993). These results indicate the burden of these diseases to society as a whole, as well as to the patient and the carer.

This study was the first nationwide investigation of genetic diseases in Korea, but to obtain clearly ascertained cases we are planning to establish a registry system for several congenital malformations and genetic disorders, via the Internet (http://www.nih.go.kr). We are also planning a validity study of medical insurance benefit data by retrieving medical records of sampled hospitals. These studies could be very helpful for elucidating the status of congenital malformations and genetic diseases in other Asian countries, as well as in Korea.

Acknowledgements We thank Mr. Eung-O Chung and Mr. In-Bong Lee, from the Korean National Federation of Medical Insurance. They helped in our investigation of medical insurance benefit data. This study was supported by a grant (HMP-97-P-0015) from the Ministry of Health and Welfare, Republic of Korea.

\section{References}

Applegate M, Druschel C (1995) The epidemiology of infantile hypertrophic pyloric stenosis in New York State 1983 to 1990. Arch Pediatr Adolesc Med 149: 1123-1129

Blackburn E, Fineman R (1994) Epidemiology of congenital hydrocephalus in Utah, 1940-1979: Report of an iatrogenically related "epidemic". Am J Med Genet 52: 123-129

Cannon C, Dildy G, Ward R, Varner M, Dudley D (1996) A population-based study of congenital diaphragmatic hernia in Utah: 1988-1994. Obstet Gynecol 87: 959-963

Chi JG (1987) Current status of congenital malformation statistics in Korea. Korean J Pediatr (in Korean) 30: 595-601

Congenital Malformations Worldwide (1991) A report from the International Clearinghouse for Birth Defects Monitoring System. Elsevier Science Publishers, Amsterdam

Connor M, Ferguson-Smith M (1997) Medical genetics. $5^{\text {th }}$ edn. Blackwell Science, Oxford, pp 177-196

Farhud D, Walizadeh G, Kamali M (1986) Congenital malformations and genetic diseases in Iranian infants. Hum Genet 74: 382-385

Ferencz C (1990) On the birth prevalence of congenital heart disease. J Am Coll Cardiol 121: 31-36 
Forfar JO (1992) Demography, vital statistics and the pattern of disease in childhood. In: Capbell AGM, McIntosh N (eds). Forfar and Arniel's textbook of paediatrics. $4^{\text {th }}$ edn. Churchill Livingstone, Edinburgh

Gillum R (1994) Epidemiology of congenital heart disease in the United States. Am Heart J 127: 919-927

Goldberg E (1984) An epidemiological study of Hirschsprung's disease. Int J Epidemiol 13: 479-485

Grabitz R, Joffres M, Collins-Nakai R (1988) Congenital heart disease: Incidence in the first year of life. Am J Epidemiol 128: 381-388

Hanna E, Nevin N, Nelson J (1994) Genetic study of congenital heart defects in Northern Ireland (1974-1978). J Med Genet 31: $858-863$

Imaizumi Y, Yamamura H, Nishikawa M, Matsuoka M, Moriyama I (1991) The prevalence at birth of congenital malformations at a maternity hospital in Osaka city, 1948-1990. Jinrui Idengaku Zasshi (in Japanese) 36: 275-287

Mosher D (1996) Disorders of blood coagulation. In: Bennet J, Plum F (eds). Cecil's textbook of medicine. $20^{\text {th }}$ edn. WB Saunders, Philadelphia

National Federation of Medical Insurance (1993) 1993 Medical
Insurance Statistical Yearbook. $16^{\text {th }}$ edn. National Federation of Medical Insurance, Korea, pp 318-319

Natsume N, Suzuki T, Kawai T (1987) The prevalence of cleft lip and palate in the Japanese: Their birth prevalence in 40,304 infants born during 1982. Oral Surg Oral Med Oral Pathol 63: 421-423

Park HK, Lee CH, Nam KH, Lee KH, Cho YH (1993) The clinical epidemioiogic study of congenital anomalies in the newborn infants. Korean J Obstet Gynecol (in Korean) 36: 1383-1390

Sever L (1982) An epidemiologic study of neural tube defects in Los Angeles County II. Etiologic factors in an area with low prevalence at birth. Teratology 25: 323-334

Thein MM, Koh D, Tan KL, Lee HP, Yip YY, Tye CY, Phoon WO (1992) Descriptive profile of birth defects among live births in Singapore. Teratology 46: 277-284

Thilen A, Larsson A (1990) Congenital adrenal hyperplasia in Sweden 1969-1986. Acta Paediatr Scand 79: 168-175

WHO Scientific Group (1996) Control of hereditary diseases. WHO Technical Report Series no 865, World Health Organisation, Geneva

Xiao KZ (1989) Epidemiology of cleft lip and cleft palate in China. Chung Hua I Hsueh Tsa Chih (in Chinese) 69: 192-194 